\title{
Steven M. Goldstein, China and Taiwan,
}

Cambridge, UK, and Malden, MA, Polity Press, 2015, 228 pp.

Jean-Pierre Cabestan

\section{(2) OpenEdition}

\section{Journals}

Electronic version

URL: http://journals.openedition.org/chinaperspectives/6997

DOI: 10.4000/chinaperspectives.6997

ISSN: 1996-4617

\section{Publisher}

Centre d'étude français sur la Chine contemporaine

\section{Printed version}

Date of publication: 1 June 2016

Number of pages: 70-71

ISSN: 2070-3449

\section{Electronic reference}

Jean-Pierre Cabestan, « Steven M. Goldstein, China and Taiwan, », China Perspectives [Online], 2016/2 I 2016, Online since 01 June 2016, connection on 10 December 2020. URL : http://

journals.openedition.org/chinaperspectives/6997 ; DOI : https://doi.org/10.4000/chinaperspectives. 6997

(c) All rights reserved 


\section{Book reviews}

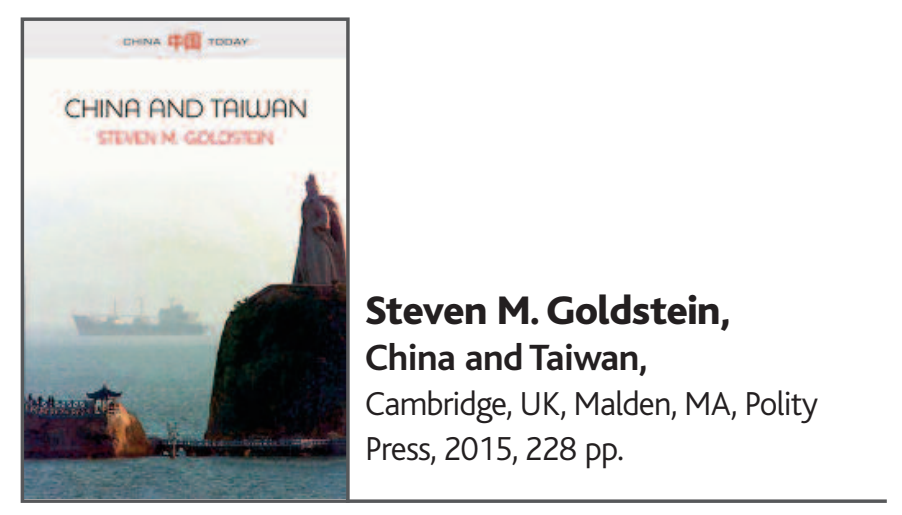

JEAN-PIERRE CABESTAN

$\mathrm{T}$ his is a very useful overview of both the history and the current state of China-Taiwan relations. The $16^{\text {th }}$ title of a new collection called "China Today," this short volume is mainly aimed at informing the general public interested in the most striking features of what is now the second world economy and power. However, written by a recognised expert of the relations across the Taiwan Strait, it constitutes both a comprehensive and highly reliable exposé of Taiwan's past, its unique trajectory, and its closer but still difficult relationship with China. Moreover, it uses newly declassified materials that underscore the complexity of the issue as well as the ambiguities attached to the positions of each stakeholder, namely China, Taiwan, and the United States. Consequently, students of Chinese affairs interested in better comprehending cross-Strait relations and Taiwan's future are strongly advised to read this book.

Organised in eight brief chapters, Steven Goldstein's work first reminds the reader about Taiwan's past, its late inclusion in the Manchu Empire (1683), the 50-year Japanese colonisation (1895-1945), and more importantly, what the United States (and Japan) still consider its "unsettled status" in spite of its claimed return to the Republic of China (ROC) in 1945. It then adroitly summarises "cross-Strait politics without relations" during the Cold War and what has changed and not changed in Washington's stance on Taiwan since Nixon's trip in 1972. Similarly, it highlights the ambiguities of the Sino-US normalisation in 1979 and the 1982 third communique (on the reduction of US arms sales to Taiwan), as well as the importance of the April 1979 Taiwan Relations Act and the refusal of all US governments, including the Carter administration, for that matter (p. 66), to endorse the idea that Taiwan is part of the People's Republic of China.

While for obvious reasons Washington looms large in this book, China and Taiwan also gives much space to Taiwanese politics. It rightly underscores what it calls "the challenges of a democratic Taiwan," the impact of democratisation, and the quest for a better statehood both on cross-Strait relations (the missile crisis) and Taipei-Washington relations (a more robust security engagement and military cooperation). Likewise, the Chen Shui-bian (and Democratic Progressive Party, DPP) presidency (2000-2008) is clearly analysed, contrasting the first two years of relative moderation with the next six years of Taiwanese identity "assertiveness" (my own wording) but also growing rapprochement between the Kuomintang (KMT) and the Chinese Communist Party (CCP). Entitled "Satisfying Washington and Beijing," the chapter devoted to the Ma Ying-jeou presidency shows both the achievements and the limits of the rapprochement initiated by the KMT and supported by most Taiwanese, at least until 2014 and the Sunflower Movement. This chapter also demonstrates that China won't be happy as long as Taiwan - one of its top "core interests" - capitulates and embraces political negotiations leading to reunification. As a result, the US cannot extricate itself from the key role it plays in this dispute.

The two final chapters present the two well-known paradoxical pillars of the relationship across the Taiwan Strait: on the one hand, a deepening but highly asymmetrical economic interdependence, and on the other hand, a lingering and unsolvable security tension that has forced the US to adopt a "dual deterrence" strategy (to deter a Chinese unprovoked attack as well as a Taiwanese declaration of independence).

There are probably choices and developments in Coldstein's book that other scholars studying cross-Strait relations may object to. For instance, he does not adequately emphasise the close connection between US-China normalisation and Deng Xiaoping's adoption of a policy of "peaceful reunification" towards Taiwan, as opposed to "peaceful liberation," a formula still used by Hua Guofeng in late 1978 (p. 53). This linkage is important because it will later justify the decision made by the Clinton administration to disregard (or de facto freeze) the application of the 1982 third US-China communiqué as Beijing decides to remilitarise the Taiwan Strait. Another criticism can be made regarding Lee Teng-hui's decision in 1999 to qualify cross-Strait relations as state-to-state relations: it was more the result of talks held by the Strait Exchange Foundation (SEF) and the Association for the Relations Across the Taiwan Strait (ARATS) in Shanghai in 1998 than the division between the Clinton administration and Congress (p. 95) that explained Lee's initiative: he did not want to open "political talks" with China, knowing too well where it might lead.

One can also question whether the Chen years were "a period of high danger" (the title of Chapter 5). Goldstein tends to dismiss Chen's caution and Beijing's unaccommodating position in the first two years of his presidency, the latter being the main reason for Chen's change of mind and strategy in summer 2002. More generally, looking back at these years as another DPP administration starts in 2016 under the presidency of Tsai Ing-wen, one wonders what Chen tried and managed to achieve. In 2006 he terminated the National Unification Council, an institution established before Taiwan's democratisation and the political legitimacy of which was questionable, but never actually challenged the "one China nature" of the Republic of China's Constitution (as mentioned on p. 102). In addition, regarding the so-called "92 Consensus," the author does not adopt enough critical distance from this concept, coined by the KMT's Su Chi in 2000: in 1992, the SEF and the ARATS reached an ambiguous compromise rather than a "consensus" regarding "one China" (p. 103), and as Tsai steps in as the new ROC president, this problem remains unsolved. Finally, while China and Taiwan does a good 
job tracing the initial statement in 2005 of Hu jintao's slightly more flexible policy towards the island, it does not mention the important change adopted by the CCP in October 2007, which elevated the priority of the "peaceful development" of cross-Strait relations (as opposed to "peaceful reunification"), an idea that goes back to the first point of Beijing's 17 May 2004 seven-point statement ${ }^{(1)}$ and means that Beijing can accept the status quo for the time being. It is a policy priority that has not been questioned by $\mathrm{Xi}$ Jinping, even if the new Chinese president has demonstrated more impatience regarding leaving the issue unresolved for future generations.

China and Taiwan closes just before the November 2015 Xi-Ma summit in Singapore and Taiwan's January 2016 presidential and legislative elections. However, it includes all the ingredients that observers need to be aware of in order to understand the current state and uncertain future of cross-Strait relations. A tour de force, as we say in English... and in French.

I Jean-Pierre Cabestan is the head of the Department of Government and International Studies at Hong Kong Baptist University (cabestan@hkbu.edu.hk).

1. Embassy of the People's Republic of China in the United States of America website, "Taiwan Affairs Office Issues Statement on Current Cross-Straits Relations," 17 May 2004, www.chinaembassy.org/eng/zt/twwt/t111117.htm (accessed on 27 April 2016).

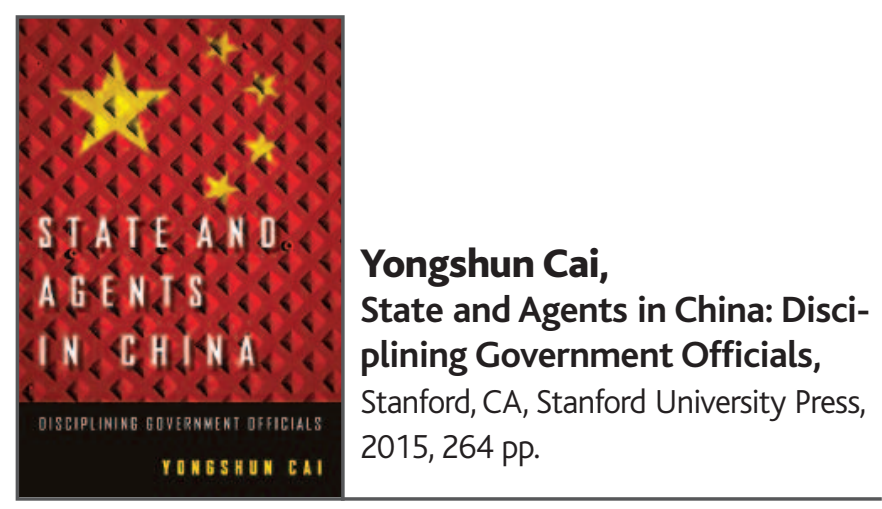

JÉRÔME DOYON

$\mathrm{T}$ his book by Yongshun Cai, professor at the Hong Kong University of Science and Technology, is concerned with the ways in which the Chinese Party-state ensures internal discipline. Presenting the issue in the formal framework of the theory of agency, he stresses the problems of information asymmetry and moral hazard at the heart of the relationship between the state and its agents. As the state is not omniscient, it does not always know what its agents do or will do, and this could lead the latter to adopt behaviours other than those expected in implementing public policies. In this situation, the state is obliged to adopt methods for disciplining its agents while taking into account possible political costs. By targeting its own cadres, the Partystate risks alienating the main supporters of a regime not based on popular elections. Keeping this risk in mind, as well as its own limited resources, the state can hardly afford to attack all its undisciplined cadres and might be obliged to be selective with rewards and punishments. Thus the state does not need to punish all violations, but only needs to make agents aware of the high level of risk they face and to induce fear of this uncertain discipline.

Major issues regarding the functioning of the Chinese state and its efforts at formalising the conduct of its actors are considered in this work in a com- parative context. However, the stylisation of conduct is double-edged: with the state set as a "principal" controlling its "agents," it appears disembodied and monolithic. While the book takes into account the different levels of the Chinese administration - this selective discipline applying to the central as well as provincial, municipal, and local levels - it is not quite clear who at each level acts as the "principal." Is it the Party secretary? Or is it a larger leadership, including the divergent interests within it? This is a fundamental question, as it would help determine the intentionality behind the disciplinary actions. This lack of clarity in defining the "principal" thus leads to a certain imprecision as regards the objectives. For Cai, the state's aim is to guarantee its effectiveness as well as its legitimacy among the public. This legitimacy concept is only vaguely defined, as a sort of moral hegemony of the state, and it is therefore difficult to grasp its motivations and link them with the interests of a particular actor. Nevertheless, the numerous cases and mechanisms detailed in the book facilitate an understanding of what underlies the selectivity in the state's discipline.

Two chapters bring detailed focus on the types of undisciplined behaviour that have grown in the contemporary Chinese state and on the political logic that explains selective and differentiated discipline. Cai pointedly notes the large number of violations reported by citizens' petitions (about 60,000 a year in Guangdong during the 1990s, p. 23) and the vast variety of acts in question, ranging from abuse of power to corruption, as well as the pursuit of irresponsible projects or a lifestyle deemed immoral. The lack of correlation between the number of complaints and the number of cadres hauled up shows the selectivity of investigations linked to a singular political logic. Whereas before the 1980s, the Chinese Party-state mainly relied on major political campaigns to bring its cadres in line, a dedicated mechanism has since been set up. In the early 2000s, nearly 300,000 cadres were in charge of internal discipline (p. 49). The model of the Party's Central Commission for Discipline Inspection, re-established in 1978, was replicated at the local level. A decentralised system of inspections was then established, with each level of the administration being in charge of disciplining the next lower level. In Cai's view, two main variables are considered in deciding to punish an agent or not: the seriousness of the consequences and the agent's level of responsibility. While this seems self-evident, this approach appears to be put in doubt by numerous cases that on the contrary point to the existence of a variety of questions being considered before arriving at a decision to punish an agent: Has the transgression been made public by the media? What factional support does the agent enjoy? What effect would such punishment have on the administration's image and agents' morale?... Thus the agent's responsibility appears to be a highly malleable element depending on the result sought by superiors and the information obtained, or not, by the press, which remains on a tight leash. Power struggles over defining the objectives of the discipline process are not to be underestimated, while the functional rationality of the state that wants to punish an agent for his transgression is not to be overestimated, as Cai tends to in the book.

In the next two chapters, the author plunges into granularity by differentiating the types of transgressions and thus punishments. Focusing at the outset on professional errors linked to the exercise of a function, as opposed to cases of corruption, he notes the large panoply of punishments possible, and the flexibility the state enjoys. By concentrating on cases of social conflict management, Cai brings out the complexity of elements at play in judging a professional error and those responsible. A cadre could well be held guilty of being responsible for a protest, but if that were not the case, he 